\title{
Mind the climate policy gaps: climate change public policy and reality in Portugal, Spain and Morocco
}

\author{
João Camargo ${ }^{1}$ (D) - Iñaki Barcena ${ }^{2}$ Pedro M. Soares ${ }^{3}$ (D) Luísa Schmidt $^{1}$ (D) \\ Javier Andaluz ${ }^{4}$
}

Received: 10 July 2019 / Accepted: 22 December 2019/Published online: 11 January 2020

(C) Springer Nature B.V. 2020

\begin{abstract}
The IPCC $1.5^{\circ} \mathrm{C}$ report argues for a $50 \%$ cut of global greenhouse gas emissions by 2030 . Dangerous gaps lie between what is required to reach the $1.5^{\circ} \mathrm{C}$ objective, what governments have pledged and what is happening in reality. Here, we develop 'climate policy gap' graphics for Portugal, Spain and Morocco to help reveal this divide and quantify the underreaction between diagnosis and action, through layers of political intended and unintended miscommunication, insufficient action and the power of the fossil fuels industries. The climate policy gaps for the three nations reveal overshoots on even the most ambitious levels of emissions reductions pledged when compared with trajectories compatible with $1.5^{\circ} \mathrm{C}$ or even $2{ }^{\circ} \mathrm{C}$ limits. This research suggests that there is a built-in feature of under-reaction in climate policy, which staves off any emission pathways compatible with stopping a temperature rise above $1.5^{\circ} \mathrm{C}$ by 2100 . It shows that the climate policy gap is a political and methodological tool that reveals systemic shortcomings of government climate action. Its visibility identifies benchmarks and sectors that should be activated to close these gaps in response to the growing popular demands for climate justice.
\end{abstract}

Keywords Climate policy gap · Climate change policy-making · Public policy under-reaction · Portugal · Spain · Morocco

\section{Introduction-a global gap}

The objective of the 2015 Paris Climate Agreement is to deter the increase in global average temperature to well below $2{ }^{\circ} \mathrm{C}$ above pre-industrial levels, with an effort to limit this increase to $1.5{ }^{\circ} \mathrm{C}$ (UNFCCC 2017). A recent projection by Climate Action Tracker puts global temperature increase with current policies at 3.1 to $3.7^{\circ} \mathrm{C}$ by 2100 (CAT 2018), with the Paris Agreement pledges settling on the path to a 2.6 to $3.2^{\circ} \mathrm{C}$. Climate policies are seen as a paradigm of under-reaction, especially in the mitigation field (Peters et al. 2017).

\section{João Camargo}

joao.camargo.342@gmail.com; jcsantos@ics.ul.pt

Extended author information available on the last page of the article 
According to Maor et al. (2017, p. 599), a policy under-reaction can be understood "as a situation in which the policy adopted by decision-makers provides net utility which is smaller than the one that would have been obtained had a different policy been enacted." The authors further add that it is characterized by slow, insufficient or non-response to a situation of increased risk.

This paper introduces and measures the concept of climate policy gaps. These reveal the divergence between intended emissions reduction pathways as laid down in national policymaking, in regulatory support and public engagement, and actual outcomes. The gap demonstrates both political under-reaction and policy failure. Its configuration reveals both where and why there is failure and pinpoints what can be done to close the gap. The aim of this research is to demonstrate that the identification and quantification of climate policy gaps can be used as a device in any country for stimulating enhanced mitigation policy delivery and for generating increased public accountability, as well as further test the built-in under-reaction in climate policies in different political and cultural scenarios identified in the literature.

In this paper, we produce climate policy gap graphics for three Mediterranean countriesPortugal, Spain and Morocco. They have been chosen for their vulnerability to climate change and relative good performance in climate policy as evaluated by international indexes. They are also countries with diverse national cultural and political backgrounds, which might have led to diverse results in terms of gaps. By evaluating the national climate policies and/or the INDCs for each country, we highlight climate policy under-reaction and seek to quantify why the global gap is widening.

Iacobuta et al. (2018) note that worldwide greenhouse gas emission targets have been adopted by countries that correspond to $89 \%$ of global GHG emissions and $80 \%$ of global populations. Currently, $70 \%$ of global emissions (corresponding to $76 \%$ of world population and $48 \%$ of countries) are covered by Intended Nationally Determined Contributions (INDCs) or national emissions strategies supported by coordinating bodies. This contradicts the continuous rise of global GHG emissions (with 2018 establishing a new record). National legislation, strategies and targets are necessary but have been proven highly unsuccessful on the global scale in failing to reduce monitored emissions. Fossil fuel subsidies for 191 countries in 2015, as estimated by the IMF (Coady et al. 2019), were of the order of US\$5.2 trillion, equivalent to $6.5 \%$ of global GDP. The largest subsidizers are China, United States, Russia, European Union and India, while renewable capacity growth has worldwide stalled in 2018 (IEA 2019).

Under-reaction in international climate policy is widespread. Spash (2016, pp. 931-932) refers that "a simple test of the effectiveness of the Paris Agreement would have been a dramatic drop in the share price of the fossil fuel industry, which is loaded with toxic assets (...). Nothing happened to the stock market because the Paris Agreement is perceived by the fossil fuel industry, and by financial markets, as no threat to business as usual, and possibly it is even a great opportunity for new financial instruments and ongoing economic exploitation of the planet, with trillions to come to the energy industry in subsidies for innovation and technology development.".

Addressing the global gap between what should happen in terms of emissions and what is happening can be a tool for decision making, political action and providing an analysis of explanation for such shortcomings, contributing to the exploration of climate policy underreaction. This is particularly relevant as in 2019 a massive social movement for climate justice expanded all over the world, in the wake of the students climate strikes (Fridays For Future) and collective acts of civil disobedience, demanding to "listen to the science" and fulfilling 
IPCC's $1.5{ }^{\circ} \mathrm{C}$ report $50 \%$ cut of global greenhouse gas emissions demand by 2030 , mobilizing millions of people worldwide for these cuts and social justice (Kühne 2019).

There are currently no proper methods to address why this under-reaction in climate policy exists, what are its reasons and how it could be fixed. Current indexes used cannot grasp this problem. In this paper, we select three countries that are labelled as relatively good performers in climate policy according to these indexes and highly vulnerable to climate change.

We have developed a multi-factorial tool, the climate policy gap, that analyses the level of mismatch between real emissions, pledged emissions and Paris Agreement compatible emissions pathways $\left(1.5^{\circ} \mathrm{C}\right.$ and $\left.2{ }^{\circ} \mathrm{C}\right)$. This tool is loosely based on an infographic called "The climate reality gap" published by a climate justice collective in Portugal called Climáximo (2018).

We demonstrate with our new methodological tool, the climate policy gap, that there are large gaps in these countries' policymaking and show why these gaps exist. Our innovative method can be used by different actors to monitor countries' emission pathways and demand more ambitious climate action from governments.

We argue that the under-reaction in climate policies is a real phenomenon, a built-in feature quantified by the climate policy gap, and that through this quantification it is possible to demand a public mandate on what can be done to close this gap, as climate stability and thus human civilization rely on successful emissions reductions delivery. We aim at establishing a bridge between climate science and public policy, by translating under-reaction into tons of carbon emissions, searching to provide science based public action on climate change. Currently, the global gap is expanding, but even countries that advertise their commitment to climate action may, in fact, be increasing their gaps through creative accounting of emissions and omission of relevant emission sources and exaggeration of carbon sinks.

\section{Case selection-Portugal, Spain and Morocco}

The choice for the three countries was made based on four criteria:

- High vulnerability to climate change and similar climate change impacts;

- Geographical proximity;

- Political, cultural and social differences;

- That the three countries, especially Portugal and Morocco, are considered international examples in successful public policy on climate change.

These criteria were selected because they are relevant for our exploration. Each country is already experiencing climate change-related stresses with high public salience. They share contiguous climate space and biogeographical continuity. They operate with varying political cultures, so examining the gaps usefully tests the efficacy of our approach. They also advertise that they are doing well in the climate policy stakes.

The quantification of the gap between stated emission pathways and Paris Agreement compatible emission pathways is a tool for political action, made more noticeable by the mounting political pressure from the climate justice movement, Blockadia, the young peoples' Fridays for Future strike action and Extinction Rebellion. The choice is further meant to illustrate how even countries that rank high in official indexes and political measurements of climate action and policy are not doing what is required to achieve what climate science reveals. 
For each country, we consider the following:

- Main climate impacts for with different Representative Concentration Pathways (RCP) scenarios (RCP 4.5 and RCP 8.5)

- Key climate legislation (laws and policies)

- Historical greenhouse emissions' trajectories in the last 30 years

- Comparison between pledges and actual emissions

- Development pathways: future industrial projects and approaches to climate change

\subsection{Portugal, Spain and Morocco, mirrors of vulnerability}

\subsubsection{Climate context and climate change impacts}

The three countries' climate is determined by the large to local scale atmospheric processes from the North Atlantic mid-latitudes and the Mediterranean Sea, and is characterized by a large inter-annual and spatial variabilities (Esteban-Parra et al. 1998; Muñoz-Díaz and Rodrigo 2004; Soares et al. 2012a; Cardoso et al. 2013; Knippertz et al. 2003; Driouech et al. 2009). This variability is also extensive to the seasonal cycle in particular for precipitation, and is enhanced by costal processes, complex topography and land-ocean-atmosphere interaction processes (Serrano et al. 1999; Soares et al. 2012b; Rios-Entenza et al. 2014; Knist et al. 2017).

\subsubsection{Future climate impacts}

The Mediterranean region, including the Iberian Peninsula (IP) and Morocco, is regarded a climate change hotspot due to projections of future increasing temperatures, decrease in rainfall amounts, sea level rises and extreme events, namely, fires, droughts, heat waves and extreme precipitation (Argüeso et al. 2012; Turco et al. 2015; Soares et al. 2017; Cardoso et al. 2018). The region is also very sensitive in terms of biodiversity, where current impacts of climate change are already being felt on land and sea, with accelerated ecosystem degradation and species loss (Lejeusne et al. 2010). There have also been mass migratory movements (Cramer et al. 2018), linking climate change, drought, displacement and social and political unrest (Kelley et al. 2017).

The regional climate model future projections at RCP8.5 predict an overall warming for the Portuguese mainland from about $6{ }^{\circ} \mathrm{C}$ in summer and autumn to between 2 and $4{ }^{\circ} \mathrm{C}$ in winter and spring in coastal regions (Cardoso et al. 2018). The projections for the end of the century indicate important losses of rainfall in spring, summer and autumn, from -10 to $-50 \%$, when compared with the historical period (Soares et al. 2017). Roughly, in agreement with the RCP4.5, the temperature increases are mitigated to values below $3{ }^{\circ} \mathrm{C}$ and the reduction of precipitation is attenuated to values between -5 and $-15 \%$ (Cardoso et al. 2018; Soares et al. 2017).

For Spain, the future projections at RCP8.5 are approximately in line with the ones for Portugal (Amblar-Francés et al. 2017). For the end of the century, the winter rainfall is also projected to be reduced by $-16 \%$ and $-4 \%$. In spring, the decrease is predicted to reach $24 \%$ and $-42 \%$ in summer and $-4 \%$ in autumn.

The mentioned projections are greatly attenuated if the RCP4.5 projections are considered: this scenario points to temperatures increases between 1.7 and $2.9^{\circ} \mathrm{C}$ and annual precipitation reductions for inland Spain below $-10 \%$. 
The projected changes in temperature and precipitation for Morocco at RCP8.5 are as well similar to the ones of Iberia but revealing a larger uncertainty for extreme precipitation. The projected temperature changes are above $4{ }^{\circ} \mathrm{C}$, in particular in the warmer northeast and southeast regions (Filahi et al. 2017). Maximum temperature is expected to increase less than minimum temperature in large regions of Morocco, except in the eastern areas. The yearly average precipitation may be reduced in more than $-30 \%$, especially in the south of Morocco, and extreme rainfall ( 1 and 5 days) is expected to augment in the northern areas but decrease in the south of the country. For the RCP4.5, these changes are reduced, e.g. the projected temperature increases are in the range of 1 to $2{ }^{\circ} \mathrm{C}$ and the annual precipitation reduction mostly below $10 \%$.

\subsection{Climate performances and analysis}

There are currently many different climate performance indexes and trackers, comparing countries with each other and evaluating shortcomings of politics, pledges and actions. We will focus on two of these analyses: the Climate Performance Index and the Climate Change Action Tracker.

The Climate Change Performance Index (CCPI 2018), developed by CAN (Climate Action Network), Germanwatch and the New Climate Institute, evaluates four dimensions:

- Greenhouse gas emissions (40\%)

- $\quad$ Renewable energy use $(20 \%)$

- Energy use (20\%)

- Climate policy $(20 \%)$

Morocco is very highly placed, rating number 5 in the world (which actually means number 2, as the first three places are left vacant, because no country in the world is considered to be doing enough to prevent catastrophic climate change). To this effect, Morocco's low energy use, low GHG emissions and high climate policy rating were decisive. Portugal comes in the 17 th position, also rating high on energy use and climate policy but with more GHG emissions. Spain comes in the 35th position (out of 59 countries and the EU) due to its very high GHG emissions level and low climate policy rating. From 2018 to 2019, all three countries have improved their rankings and ratings in general. In terms of climate policy, Portugal and Morocco rank at the very top (number one and number five, respectively).

The Climate Change Action Tracker (CAT) tool aims at providing independent scientific analyses run by a consortium of three research organizations: Climate Analytics, New Climate Institute and Ecofys, with the collaboration of the Potsdam Institute for Climate Impact Research (PIK).

The CAT (2018) compares 39 countries' INDCs with interpretations of fairness (including historical responsibility, capability and equality), evaluating the emission levels resulting from emission reduction commitments against effort sharing benchmarks in each country. It further provides an evaluation of countries' efforts as regards the Paris Climate Agreements targets of 1.5 and $2{ }^{\circ} \mathrm{C}$.

As in the Climate Change Performance Index, Morocco is very well placed, with a status of "1.5 ${ }^{\circ} \mathrm{C}$ Paris Agreement Compatible," while Portugal and Spain, grouped inside the European Union evaluation, are rated "Insufficient." 
CAT also evaluates current policy rating and climate policy progress since 2015 . In this regard, Morocco is evaluated as "Best in Class" and $1.5^{\circ} \mathrm{C}$ Paris Agreement compatible, with "clear progress" made since 2015. Portugal and Spain, evaluated in the EU, fall in the category of "moving, but a long way to go" and "highly insufficient" in terms of the Paris Agreement but also with "clear progress" made since 2015.

The combined analysis of Climate Change Performance Index and Climate Action Tracker provides important information about these three countries' climate policies, as well as their pledges/targets and GHG emissions' pathways. The evaluation of policy is positive, while emissions' pathways are judged negative (which is contradictory in itself).

\subsection{Key climate legislation}

\subsubsection{Portugal}

Portugal's political and institutional frameworks on climate change were developed in the 1990s, after the ratification of the United Nations Framework Convention on Climate Change in 1992 and, especially, after the signature of the Kyoto Protocol in 1998 (ratified in 2002) (Carvalho et al. 2014). While most EU countries pledged to reduce their GHG emissions, under the 1998 Burden Sharing Agreement, Portugal benefited from a moratorium to compensate its economic backwardness, having even been authorized to increase its emissions to a maximum of $27 \%$ by 2008/2012 (compared with 1990), the highest rise allowed in the EU-15 member states (Aidt and Greiner 2002).

2015 was a landmark in the field of national policy for climate change, with the approval of the Strategic Framework for Climate Policy, including the approval of a third National Climate Change Program (PNAC 2020-2030), a new National Strategy for Adaptation to Climate Change (ENAAC 2020) and the creation of the Interministerial Commission on Air and Climate Change (CIAAC). The period 2015-2016 was marked by the elaboration of Municipal Strategies for Adaptation to Climate Change in 26 municipalities throughout the country (one per intermunicipal community), including Lisbon and Porto.

In 2016, Portugal ratified the Paris Agreement and in 2018 the Climate Change Adaptation Program of Action (P-3 AC) was presented for public consultation. This program complements and systematizes the work carried out in the context of ENAAC 2020, focusing on its second objective - the implementation of adaptation measures. It outlines eight action lines for direct intervention in the territory and infrastructures. These action lines include the development of decision support tools, as well as capacity-building and awareness raising actions.

Portugal's Nationally Determined Contribution was jointly submitted with the rest of the 28 Member States of the European Union (including Spain), and it has an unconditional target of at least 40\% domestic reduction in GHG emissions by 2030 compared with 1990 (Portugal's individual pledge is only of $17 \%$ ).

The elaboration of the National Integrated Energy and Climate Plan (PNIEC) in 2019 consists of a new energy and climate policy instrument for the decade 2021-2030, in line with three main objectives: to give priority to energy efficiency, to achieve world leadership in energy renewable sources and to ensure more equity among energy consumers. There was also a public consultation on the Roadmap for Carbon Neutrality 2050, which has the general objective of technically supporting the commitment made by Portugal to achieve the carbon neutrality of its economy by 2050. This includes specific transition pathways for the sectors of energy, mobility and transportation, industry, the residential and service sector, agriculture and 
forestry and waste management (including the transitions induced by the circular economy). In terms of emissions, the PNIEC pledges 45-55\% emissions cuts by 2030 (base 2005). By choosing the 2005 emission-peak as base, instead of 1990 or 2016/2017, the pledge implies only a $35 \%$ emission cut (base 2016).

\subsubsection{Spain}

The National Climate Change Adaptation Plan (PNACC) was approved in 2006, stipulating the implementation of work programs (to prioritize areas and structure activities) every 8 years, containing actions at state level, as well as strategic lines for different local and regional entities. In terms of mitigation, legislation on climate change remains strictly sectoral, and the initiative for producing legislation has been mainly the adoption of European directives and mandates.

The lack of a general framework and the decentralized competences in Spain has generated important policy stresses. Some regions have taken the initiative quicker than the central administration, creating numerous conflicts of competence. The most relevant case was the proposed Catalan Law on Climate Change, legally challenged by the central government (BOE 2017). This ruling blocked carbon budgets, regional emissions inventories and climate change adaptation regulations. The same government vetoed the proposal of law of the Government of the Balearic Islands (BOCG 2017) prohibiting oil exploration, as well as the scheduled end of electricity production with coal in the island territories (El Pais 2018).

There is a clear political divide over climate change policies in Spain with the more leftwing leaning parties favouring more progressive action. Such is the case with the renewables self-consumption regulation RD 1699/2011, which facilitated self-consumption by allowing small energy producing units from renewable sources to connect to the national grid, approved by a PSOE (Socialist Party) government.

Projections point to an increase in GHG emissions in all sectors. Transport will experience the highest growth (including flights and maritime transport). The tourism sector will also become one of the most important emitters, while the waste sector stands to have a significant reduction in emissions. In the last official emissions projections by the government (MAPAMA 2017), published in March 2017, Spanish emissions are expected to rise $15 \%$ by 2030 and by $27 \%$ by 2050 compared with 1990 levels.

\subsubsection{Morocco}

Morocco ratified its entrance to the UNFCCC in 1995, the same year its National Strategy for Sustainable Development and Environment was adopted, joining the Kyoto Protocol in 2002. In 2008, the National Plan of Priority Actions (PNAP) and the Morocco Energy Strategy (SEN) were launched, with its main axis being the security of supply and diversification of fuel types and origins, access to energy for all society at competitive prices, promotion of renewable energy and energy efficiency and regional energy integration in the euroMediterranean markets (Koskou et al. 2015).

Morocco's Nationally Determined Contribution (CDN 2016) established an unconditional compromise of $17 \%$ reduction of GHG emissions by 2030 when compared with the BAU (Business as Usual) scenario, with $4 \%$ reduction in LULUCF (Land Use, Land Use Change and Forestry) and $13 \%$ in the remaining sectors, with a conditional compromise of an additional 25\% reduction when compared with BAU scenario (also including LULUCF), 
which could amount in total to a $42 \%$ emission reduction compared with BAU. This additional reduction is conditional on obtaining 24 billion USD in financial support.

Table 1 summarizes the most important legislation in the three countries regarding climate change mitigation and pledges to cut GHG emissions.

\subsection{Development pathways: future industrial projects and approaches to climate change}

Portugal's climate policy as regards energy is limited by the private ownership of the biggest providers and distributors of electricity, EDP and REN (controlled by the Chinese government). The shift that has occurred in the last two decades, with an important rise in renewables use for electricity, especially through wind power, was led by private companies through high government subsidies, giving rise to higher energy costs. Most of political initiative on energy still focuses on the issues of prices, overcosts and the continuous flow of public money into energy companies' shareholders (Camargo 2018), with decarbonization being more of a side effect than a focus of energy public policy.

Currently, Portugal's highest emitting sectors are electricity production and distribution (EDP, REN, Tejo Energia) transport and fuel (GALP Energia), paper pulp (The Navigator Company, Altri Florestal) and cement (Secil, Cimpor).

Table 1 Summary of mitigation of GHG emissions pledges in Portugal, Spain and Morocco

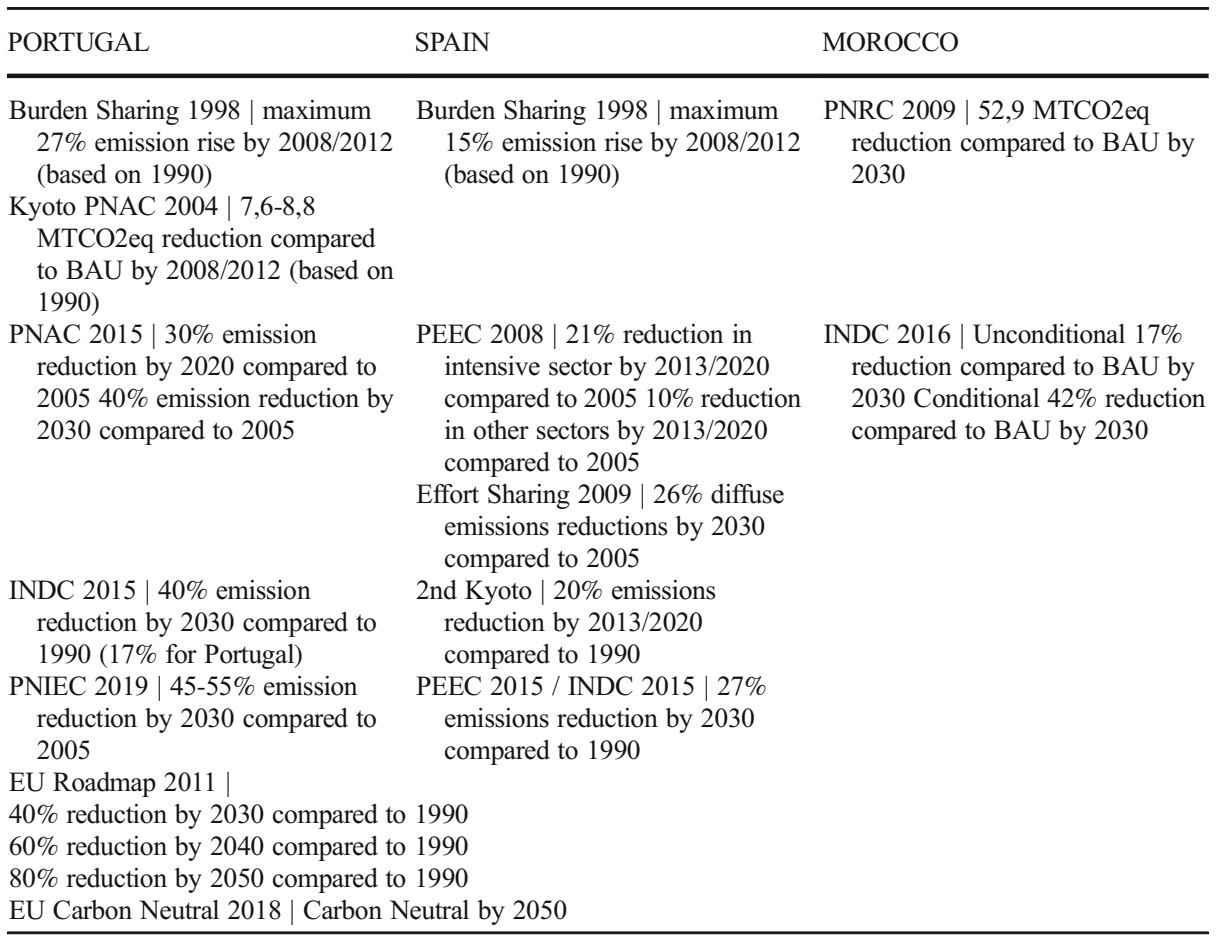


Spain is a country highly dependent on the import of fossil fuels and whose use has been a source of high greenhouse gas emissions, lacking policies capable of curbing such emissions. The various Spanish governments of the last three decades have opted for natural gas as a fuel for energy transition, which has led to an oversized policy of under-utilized gas provision (facilities operate at $13 \%$ of capacity). Spain has more than $30 \%$ of the total regasification capacity of the EU (4th country in the world). According to the Observatory of Sustainability, ten Spanish companies create 28\% of total emissions (OS 2017). The agricultural sector emissions in the year 2017 were $11 \%$ of the total, (increased by $2.9 \%$ over the previous year).

Morocco's public and political discourse on climate change is internationally acclaimed. The country is one of the least responsible for climate change and one that is set to be most affected by it and least prepared for the impacts of global warming. Yet there are signs of sophistry. There has been significant investment and growth in wind power plants, big hydraulic dams and solar power plants. But investment in new fossil fuel projects reveal, much as in Portugal and Spain, that counteracting decarbonizing economies, are policies attracting diversified energy investment, underwritten by the state.

The agricultural strategy, outlined in the Plan Maroc Vert, promotes "high added value" cash crops, with agricultural intensification of production for export, namely of citrus and fruits that consume lots of water, competing with subsistence farming and cereal production. This has led to an increased dependency on food imports (Saidi and Diouri 2017). Moustakbal (2017) points to the convergence of three factors - political despotism, economic liberalism and climate change - as overlapping and converging processes. He identifies public policy on climate change in Morocco as "elite environmentalism," in which the state and public sectors both see the ecological crisis as an opportunity for enrichment and accumulation of additional profits, focusing more on energy production projects, which are highly profitable under publicprivate partnerships, rather than mitigation efforts, which do not shoulder the public responsibility of financing these projects through hikes in energy prices and the draining of state finances. All three countries expect and work towards higher economic growth in the future, not having a clear explanation of how this may be achieved while fulfilling decarbonisation pledges, something that can be seen quite clearly in an economic sector such as tourism.

\subsubsection{National contexts, politics and cultures}

The three countries have different political systems. Portugal is a constitutional parliamentary republic, while Spain and Morocco are constitutional parliamentary monarchies. Portugal and Spain's population are mainly catholic, while Morocco is mainly of Muslim faith. Portugal and Spain are secular states, while Morocco is a confessional state, with the King holding the title "Commander of the Faithful" and Islam being the state religion.

According to the Democracy Perception Index, 51\% of Moroccans never or rarely feel free to share their political opinions in public if most people disagree with that opinion. This perception index drops to 38\% and 35\%, in Spain and Portugal, respectively. According to the IMF's 2019 estimate, Spain has the 13th highest GDP level in the world, with Portugal having the 47th and Morocco the 58th. In the 2018 Human Development Index, based on life expectancy, per capita income and education levels, Spain ranks 26th in the world and Portugal ranks 41st, while Morocco is at 123 rd position. The first two are rated as having "very high human development", while the latter is two levels down, with "medium human development". Portugal and Spain are members of the European Union, with high economic and infrastructural development, while Morocco still ranks as a developing country, despite recent infrastructural advances. 
Portugal and Morocco have a very high public acknowledgement of climate change. Morocco held two high level summits of the UNFCCC in the past - COP7 in 2001 and COP22 in 2016. The governments of Portugal and Morocco also have high profile public communications strategies on their commitment to fight climate change, something that is not so clear in Spain (although the recent government has created an Ecological Transition Ministry focused on energy and climate change). Portugal also created a Ministry for the Environment and Energy Transition. All three countries have important legislative documents on climate change mitigation and adaptation on national, subnational and sectoral levels. Spain is one of the biggest greenhouse gas emitters in Europe (the European Union being the third largest GHG emitter in the world). These differences are important as they could theoretically lead to different outcomes in climate policy through different decision-making processes affected by the political architectures and cultural landscapes. By having different political organizations, diverse degrees of public participation and diverse civil society organizations (such as religious ones) influencing differently in the final policies, different outcomes should be expected.

\section{Materials and methods-climate policy gaps}

The climate policy gaps for Portugal, Spain and Morocco were obtained through the comparison of historical emissions (OECDStat 2019; EEA 2018; MTE 2019; MEMEE 2016; Meinhausen and Alexander 2017), the emission pathways according to the latest and most ambitious pledges made by each country (not necessarily the INDCs) and the $1.5^{\circ} \mathrm{C}$ and $2{ }^{\circ} \mathrm{C}$ future emission pathways as defined by Paris Equity Check (2019) and Robiou du Pont and Meinshausen (2018).

We have used more updated databases to construct our climate policy gaps, which generated a steeper decrease immediately after the historical emissions, which we extended up to 2017 (for Portugal and Spain) and up to 2015 (for Morocco). Figures 1, 2 and 3 are the climate policy gaps for the countries analysed.

There are at least four more aspects that need to be addressed to complete the interpretation of these climate policy gaps, which are difficult to integrate numerically:

- Uncertainty in terms of LULUCF (Land Use, Land Use Change and Forestry), namely connected to the alteration of soil emissions due to variable trends in terms of agricultural activity and intensification, forestry and forest fires;

- General uncertainty in terms of inventory, which rely mostly on voluntary submission of yearly emissions by industrial units and activity sectors;

- Omission of emissions regarding aviation and shipping;

- Omission of future industrial projects in emission pathways presented by countries.

In general these uncertainties and omissions will increase the emissions profile (current and future), further increasing the calculated climate policy gaps. This means that if any of these countries does not fulfil their pledge, as has happened in the past, the distance to a $1.5^{\circ} \mathrm{C}$ future will further increase.

\subsection{What's the overshoot and what does it mean?}

The climate policy gaps reveal important overshoots for the three countries and pledges and point to the need of much more ambitious climate policies and emission pathways, all of which 


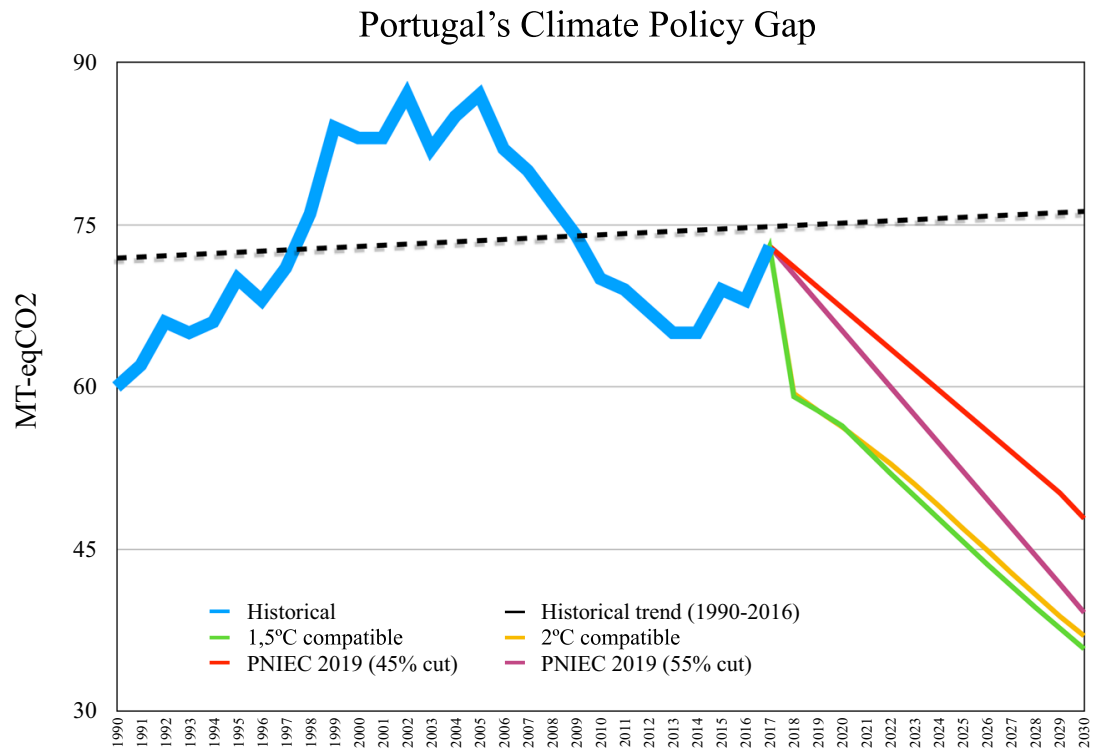

Fig. 1 Portugal's climate policy gap

need to start a steep decline in emissions immediately. They also confirm the built-in underreaction in climate policy.

Spain is the case with the highest overshoot, and, although Morocco reveals relevant gaps, contrary to Portugal and Spain, the gap relates to no increases of emissions in the short term. Portugal seems to be the country closest to achieving an emission pathway compatible to the

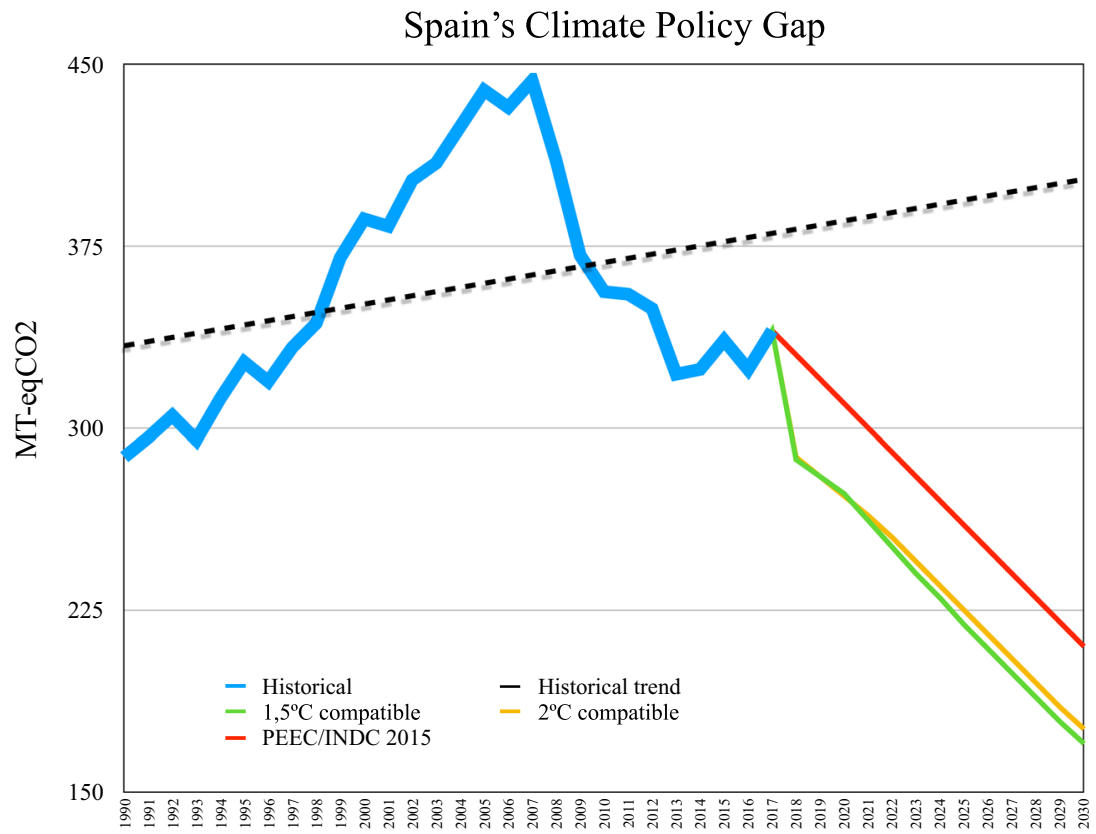

Fig. 2 Spain's climate policy gap 


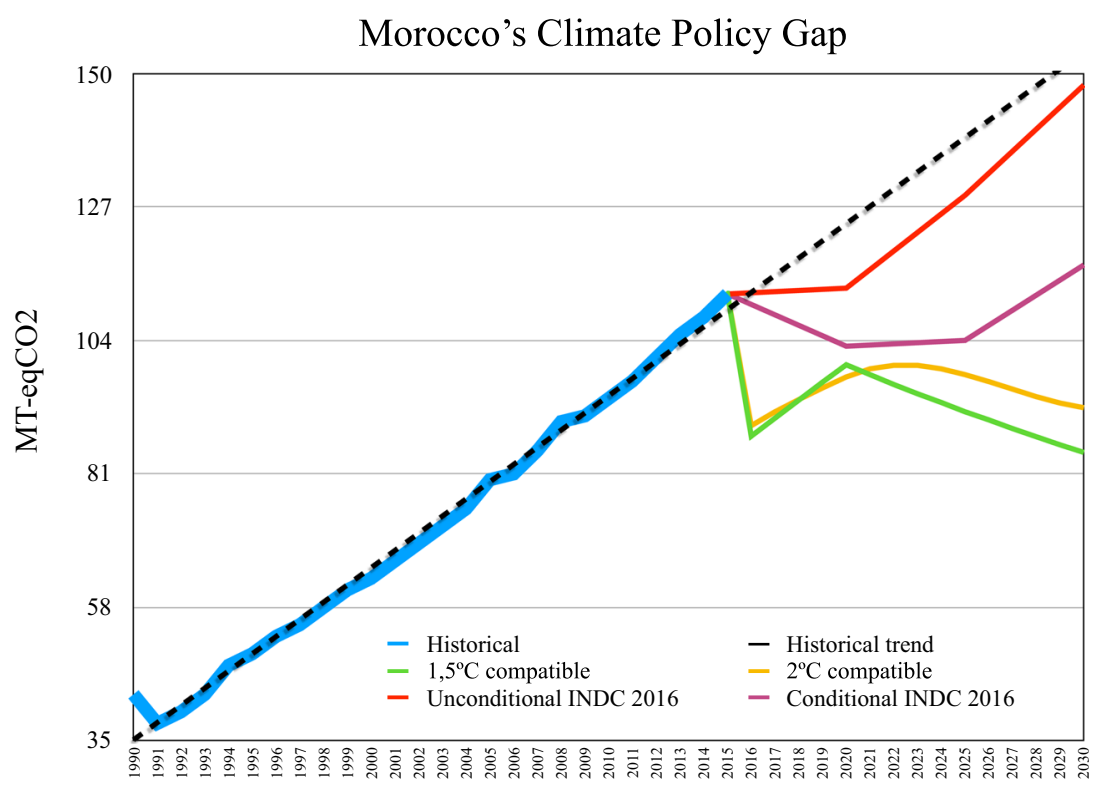

Fig. 3 Morocco's climate policy gap

Paris Agreement, but the gap-widening uncertainty factors connected to LULUCF, forest fires, inventory, aviation, shipping and future industrial projects aggravate the gaps and further increase the need for immediate decline in GHG emissions for Portugal and Spain.

Portugal's climate policy gap reveals, by 2030 ,

- A 2.15 MTCO2eq gap comparing the current highest ambition pledge of 55\% emission cuts with the $2{ }^{\circ} \mathrm{C}$ compatible emission pathway;

- A 3.35 MTCO2eq gap comparing the current highest ambition pledge of 55\% emission cuts with the $1.5^{\circ} \mathrm{C}$ compatible emission pathway;

- A $10.85 \mathrm{MTCO} 2 \mathrm{eq}$ gap comparing the more modest ambition pledge of $45 \%$ emission cuts with the $2{ }^{\circ} \mathrm{C}$ compatible emission pathway;

- A 12.05 MTCO2eq gap comparing the more modest ambition pledge of $45 \%$ emission cuts with the $1.5^{\circ} \mathrm{C}$ compatible emission pathway;

- A $11.95 \mathrm{MTCO} 2 \mathrm{eq}$ gap comparing the EU general roadmap pledge of $80 \%$ emission cuts by 2050 (based in 1990) with the $2{ }^{\circ} \mathrm{C}$ compatible emission pathway

- A 13.15 MTCO2es gap comparing the EU general roadmap pledge of $80 \%$ emission cuts by 2050 (based in 1990) with the $1.5^{\circ} \mathrm{C}$ compatible emission pathway.

Spain's climate policy gap reveals, by 2030 ,

- A 34 MTCO2eq gap comparing the current pledge (INDC/PEEC 2015) with the $2{ }^{\circ} \mathrm{C}$ compatible emission pathway;

- A 40 MTCO2eq gap comparing the current pledge (INDC/PEEC 2015) with the $1.5^{\circ} \mathrm{C}$ compatible emission pathway;

- A 52.2 MTCO2eq gap comparing the EU general roadmap pledge of $80 \%$ emission cuts by 2050 (based in 1990) with the $2{ }^{\circ} \mathrm{C}$ compatible emission pathway 
- A 58.2 MTCO2eq gap comparing the EU general roadmap pledge of $80 \%$ emission cuts by 2050 (based in 1990) with the $1.5^{\circ} \mathrm{C}$ compatible emission pathway.

Morocco's climate policy gap reveals, by 2030,

- A 55.6 MTCO2eq gap comparing the current unconditional pledge (INDC 2016) with the $2{ }^{\circ} \mathrm{C}$ compatible emission pathway;

- A 63.3 MTCO2eq gap comparing the current unconditional pledge (INDC 2016) with the $1.5^{\circ} \mathrm{C}$ compatible emission pathway;

- A 24.6 MTCO2eq gap comparing the current conditional pledge (INDC 2016) with the $2{ }^{\circ} \mathrm{C}$ compatible emission pathway

- A 32.2 MTCO2eq gap comparing the current conditional pledge (INDC 2016) with the $1.5^{\circ} \mathrm{C}$ compatible emission pathway.

Due to the uncertainty factors, these gaps are certainly underestimated. This means that even these specifically chosen countries, connected by high climate change impacts, respectable international evaluation of climate policies are not fulfilling their needed action on climate change. The world is not delivering, and individual countries are not either. The global gap is widening and the uncertainty factors, namely the expansion of economic activity, and the hegemony of the fossil fuel interests and lobbies, may prove that even in these countries, the gap is likely to widen further. The fact that even countries with very different political systems and cultural backgrounds produce similar outcomes in terms of the climate policy gaps reaffirms the built-in characteristic of under-reaction in climate policy.

\subsection{Closing the gaps}

Through the knowledge acquired in producing the climate policy gap and choosing the countries for its application, we suggest short-term sectoral benchmarks to close these gaps:

In Portugal, expansion of the solar energy sector must be accompanied by a very short-term (1-3 years) decommissioning of its coal-power plants and a decade plan to shut down its combined cycle natural gas power plants and oil refineries. Portugal needs to shift its transport system onto the expansion of railways and very affordable and extensive electric public transportation. There is a planned new airport and expansion of current seaports, both to receive increased amounts of cruise ships and cargo ships. A controversial proposal is the declared intention of receiving fracked gas for export into Europe through Portugal's hinterland. The country should further cancel its current oil and gas contracts, changing legislation to prevent new concessions. These projects hinder political will and investment out of decarbonization and support the extension of fossil fuels industries' profitability and rising GHG emissions.

Most of Spain's countries emissions come from transportation, with both cargo and passengers saddled with fossil fuels. As in Portugal, there is a push for the expansion of ports and airports, as well as the establishment of connections into central Europe for imported fossil energy. The deadline of shutting down coal and gas power plants and expanding both solar and windpower (in Spain the energy cooperative sector is quite vibrant) by 2024 should be speeded up. It should cancel all its oil and gas contracts and revoke the legislation that allowed them in the first place. The close energy interconnections between Portugal and Spain can be an important tool for this fast transition. Intensive livestock rearing is also an important methane 
emitter in Spain whose planned further expansion should be discouraged, along with its massive industry of tourism.

Morocco's different pathways include mostly the need to stabilize emissions fast and to begin a slower descent. This means blocking any new coal projects and rescinding the many current oil and gas concessions. Morocco should receive technological and financial support to further boost its renewable energy sector and create an effective and affordable public transportation system, further expanding its railway lines.

The inevitable political frictions associated with any of these actions reveal why underreaction occurs in climate mitigation. The political power relations inside each country, the networks between political and economical interests, as well as an overall systemic bias favouring an overwhelming global capitalist technopositivist perspective, constructs a worldview that ultimately blocks any meaningful move to low carbon transitions, necessarily requiring a seismic shift in current power relations. These are maintained by the recurrent revolving doors between politics and business in Portugal and Spain, with the board members of the biggest emitters often being a who's who of previous governments (as examples, EDP's $\mathrm{CEO}$ is the former Portuguese minister of Public Works and Transports and previously was GALP Energia's CEO and the EU's commissioner for Energy and Climate Action is the former Spanish minister for Agriculture, Food and Environment and, previous to that, was CEO of his family's oil companies, Petrolífera Ducar and Petrologis Canarias) (Huter et al. 2018; Camargo 2018). In Morocco, the frontier between public and private spheres is often inexistent. The biggest emitters in these countries organize massive pressure groups and think tanks, such as business councils for sustainable development, which actively influence, water down and block effective climate policy, heavily influencing public opinion through media and advertisement.

\section{Conclusions: mind the climate policy gap, a guide for immediate policy change}

In the three countries there is a general acknowledgement of the importance of the issue of climate change and its recognition in the formulation of public policies. Two out of these three countries-Portugal and Morocco - are considered climate policy champions, as can be seen in the climate performance indexes and trackers. But even the third country, Spain, can be generally analysed as being near the forefront of countries that address climate change, even if the main driver for its policies is the European Union. The fact that they have such a positive rating when the emission pathways connected to their climate policies progressively diverge from being Paris Agreement compatible also reveals many shortcomings in the indexes and trackers: declarations of intentions are still accepted as truth. We are visualizing a "vanguard" of countries that have developed complex and sectoral policies for climate change, and that have begun to put climate policies in an important place in terms of government action. These countries have expanded their renewable energy sectors very significantly. Yet, even if their emission pledges were absolutely fulfilled, the $2{ }^{\circ} \mathrm{C}$ and especially the $1.5^{\circ} \mathrm{C}$ targets by 2100 will not be attained.

These three countries represent diversity in action and decision making, yet they suffer from not only similar problems in the application of their climate policies but also in the design of these policies. The logic presiding over the mitigation of GHG emissions, the transition process, in particular in the energy sector, even in these highly vulnerable, climate policy 
vanguard countries, still aims almost exclusively to expand energy sourcing in diversified forms, including both fossil fuels and renewable energy. Climate mitigation policies are not only a paradigm or model for under-reaction in public policy, as referenced in the literature review: we argue that under-reaction is an intrinsical feature of these policies. The climate policy gap exposes built-in institutional failure through under-reaction in climate policy. The explanation for these institutional failures is multi-factorial, and the failures are also systemic:

1) There's no institutional arrangement, no political body nor regulator established to audit and monitor emissions pathways in an integrated way;

2) There are no clear shared visions of low carbon development pathways (such as the Green New Deal or any arrangement of that sort);

3) The urgency of action is mostly not part of public discourse and there is only beginnings of deliverable social rhetoric on the climate crisis;

4) There is still an educational hollow, both in schools and everyday life, on the immediate need for this unparalleled rapid shift in the economy and in social understanding and commitment.

There is a growing popular outcry, represented by the climate strikes and the global Climate Justice movement mounting pressure for a dramatic shift in public policy, an outcry that is growing steadily and fast.

The climate policy gaps calculated here display the failure to reach $1.5 / 2{ }^{\circ} \mathrm{C}$ emission compatible pathways. There is a power relations barrier of systemic character here: the continuing political support for the fossil fuels industry, its immense power in international and trade relations, the intertwined connection between energy fluxes and political and economic power, the absolute failure to disconnect economic growth from carbon emissions and the unwillingness to plan a stabilization of economic output. These overarching arguments are summarized by Klein (2019), while a detailed analysis of the overwhelming and presently unstoppable role of the fossil fuels industry is compellingly outlined by Heede (2019). This is reinforced in a background of global capitalist technopositivist policy framing, which also helps to explain the endemic institutional failures. The climate policy gap is a tool that would enable these movements to demand action on the national level, based on these national mitigation performance assessments, by systematically quantifying the shortcomings in climate policy rather than depending on the level of trust attributed to political discourse.

These graphics can be updated yearly and made public and could be set as the basis for a legal mandate of emissions' cuts to net zero levels. The identification of the actors and sectors responsible for emissions and liabilities would also be an important lever in deconstructing the power relations that maintain and seek to expand these gaps, as exemplified here.

The climate policy gaps of these three countries confirm the built-in nature of underreaction in climate policy, staving off meaningful action, even in countries that thoroughly recognize the problem. Addressing the quantified institutional and regulatory failures, both systemic and specific, should form the main guidance for immediate climate policy change and for heightened public engagement and protest.

From a research perspective, here is scope for science-based public action monitored on an annual basis, which projects the manifest public anger over inaction into focussed dialogue with the principal players. Our work shows that, even now, the climate policy gap fulfils this vital purpose. There is a complementary research effort still required to calibrate and refine the methodologies of the climate policy gap as we have intended here so it becomes an 
indispensible methodologically rigorous tool in the emerging struggle to cut $50 \%$ of global GHG emissions by 2030 and get to net zero by the middle of the century.

Acknowledgements We would like to thank Professor Tim O'Riordan from the University of East Anglia for his invaluable suggestions and critiques of this article, which have made it a much more coherent and solid piece in the giant puzzle that is climate policy and climate politics.

Author contributions João Camargo conceived the idea for the article and designed its structure, was responsible for the literature review, for the key climate legislation analysis for Morocco, for the compilation of historical greenhouses gas emissions in the last 30 years in the three countries, for the comparison between pledges and emissions, for the future development pathways for Portugal and for the development of the Climate Policy Gaps for the three countries. Iñaki Barcena and Javier Andaluz were responsible for the key climate legislation analysis and future development pathways for Spain. Pedro Matos Soares was responsible for climate context and future climate impacts for the three countries. Luísa Schmidt was responsible for key climate legislation analysis and future development pathways for Portugal. All the authors participated in discussion and conclusions.

Funding information This work was supported by the Fundação para a Ciência e Tecnologia (MCTES) under Grant PD/BD/114049/2015

\section{Compliance with ethical standards}

Conflict of interest The authors declare that they have no conflict of interest.

\section{References}

Aidt T, Greiner S (2002) Sharing the climate policy burden in the EU. HWWA Institut für Wirtschaftsforschung Discussion Paper 176

Amblar-Francés P, Casado-Calle MJ, Pastor-Saavedra MA, Ramos-Calzado P, Rodríguez-Camino E (2017) Guía de escenarios regionalizados de cambio climático sobre España a partir de los resultados del IPCC-AR5 [Guide for regional scenarios of climate change for Spain on the IPCC-AR5 results]. In: Ministerio de Agricultura y Pesca. Medio, Alimentación y

Argüeso D, Hidalgo-Muñoz J, Gámiz-Fortis S, Esteban-Parra M, Castro-Díez Y (2012) High-resolution projections of mean and extreme precipitation over Spain using the WRF model (2070-2099 versus 1970-1999). J Geophys Res 117:D12108. https://doi.org/10.1029/2011JD017399

BOCG (2017) Proposición de Ley sobre la protección del mar Mediterráneo bajo la jurisdicción española de los daños que pueda producir la exploración, la investigación y la explotación de hidrocarburos y otras sustancias minerales. [ Legislative proposal about Mediterranean Sea protection and Spanish jurisdiction that prohibits exploration, research and production of hydrocarburants and other mineral substances]. Boletín Oficial de Las Cortes Generales, Congreso de los Diputados, num123-1, 19 May 2017. http://www. congreso.es/public_oficiales/L12/CONG/BOCG/B/BOCG-12-B-123-1.PDF

BOE (2017) Recurso de inconstitucionalidad $n .^{\circ}$ 5334-2017, contra determinados preceptos de la Ley de la Generalidad de Cataluña 16/2017, de 1 de agosto, del Cambio Climático. [Inconstitutionality appeal nr 5334-2017, against certain precepts of the Climate Change Law from the Generalidad of Catalonia 16/2017, from August 1st]- Boletín Oficial del Estado, num: 294, 4 December 2017. https:/www.boe. es/boe/dias/2017/12/04/pdfs/BOE-A-2017-14164.pdf

Camargo, J. (2018). Transición democrática energética en Portugal. Investigación "Transición democrática energética - Una visión internacional y local" [Energy democratic transition in Portugal. Research "Democratic Energy Transition - An international and local vision]. Tradener (Universidad del Pais Vasco, Ekologistak Martxan and Ingeniería Sin Fronteras País Vasco) Available at https://issuu. com/ekologistakmartxanboletina/docs/portugal_transicio_n_energetica_tra

Cardoso R, Soares P, Miranda P, Belo-Pereira M (2013) WRF high resolution simulation of Iberian mean and extreme precipitation climate. International Journal of Climatology 33(11):2591-2608. https://doi. org/10.1002/joc.3616 
Cardoso R, Soares P, Lima D, Miranda P (2018) Mean and extreme temperatures in a warming climate: EURO CORDEX and WRF regional climate high-resolution projections for Portugal. Clim Dyn. https://oi. org/10.1007/s00382-018-4124-4

Carvalho, A., Schmidt, L., Santos, F. \& Delicado, A. (2014). Climate change research and policy in Portugal Wiley Interdisciplinary Reviews: Climate Change Vol. 5(2) 199-217

CAT (2018). Some progress since Paris but not enough, as governments amble towards $3^{\circ} \mathrm{C}$ of warming, Climate Action Tracker Report December 2018

CCPI (2018) Results 2019. Climate Action Network, Germanwatch, New Climate Institute

CDN (2016). Contribution Déterminée au niveau National. [Nationally Determined Contribution]. Royaume du Maroc 2016

Climáximo (2018). Climate reality gap - infographics. Available in: https://climaximo.wordpress.com/2018/05 /25/climate-reality-gap-infographics/

Coady D, Parry I, Le N and Shang B (2019). Global fossil fuel subsidies remain large: an update based on country-level estimates. IMF working paper no. 19/89 - fiscal affairs department. ISBN/ISSN: $9781484393178 / 1018-5941$

Cramer W, Guiot J, Fader M, Garrabou J, Gattuso J, Iglesias A, Lange M, Lionello P, Llasat M, Paz S, Peñuelas J, Snoussi M, Toreti A, Tsimplis M, Xoplaki E (2018) Climate change and interconnected risks to sustainable development in the Mediterranean. Nature Climate Change 8:972-980. https://doi.org/10.1038 /s41558-018-0299-2

Driouech F, Déqué M, Mokssit A (2009) Numerical simulation of the probability distribution function of precipitation over Morocco. Clim Dyn 32(7-8):1055-1063

EEA (2018). Recent trends and projections in EU greenhouse gas emissions. European Environmental Agency (October 2018)

El Pais (2018). Baleares desafia a Nadal y legislará para cerrar su central de carbón, [Baleares challenges Nadal and will legislate to close coal power plant] Bohorquez, L Planelles, M El Pais web, 15 February 2018 https:/elpais.com/economia/2018/02/15/actualidad/1518692770_406696.html

Esteban-Parra M, Rodrigo F, Castro-Diéz Y (1998) Spatial and temporal patterns of precipitation in Spain for the period 1880-1992. Int J Climatol 18:1557-1574

Filahi S, Tramblay Y, Mouhir L, Diaconescu E (2017) Projected changes in temperature and precipitation indices in Morocco from high-resolution regional climate models. Int J Climatol 37(14):4846-4863

Heede R (2019) Carbon majors: updating activity data, adding entities, \& calculating emissions: a training manual. Climate Accountability Institute, Snowmass, Colorado, September, 56 pp

Huter M, Polfliet A, Cummins-Tripodi P, Kopečný O, Gandalovičová L, Lecerf C, Müller J, Fülöp O, Zagarella A, Szulecki K, Reyes O, Selling N \& Rowell A (2018). Revolving doors and the fossil fuel industry: time to tackle conflicts of interest in climate policy-making. Greens/EFA Group in the European Parliament

Iacobuta G, Dubash N, Upadhyaya P, Deribe M, Höhne N (2018) National climate change mitigation legislation, strategy and targets: a global update. Clim Pol 18(9):1114-1132. https://doi.org/10.1080 /14693062.2018.1489772

IEA (2019). Renewable capacity growth worldwide stalled in 2018 after two decades of strong expansion. International Energy Agency Newsroom, 6 May 2019

Kelley C, Mohtadi S, Cane M, Seager R, Kushnir Y (2017) Commentary on the Syria case: climate as a contributing factor. Political Geography xxx:1-3. https://doi.org/10.1016/j.polgeo.2017.06.013

Klein N (2019) On fire: the burning case for a green new Deal. Allen Lane, London

Knippertz P, Christoph M, Speth P (2003) Long-term precipitation variability in Morocco and the link to the large-scale circulation in recent and future climates. Meteorog Atmos Phys 83(1-2):67-88

Knist S, Goergen K, Simmer C, Colette A, Cardoso R, Fealy R, Fernandez J, Garcia-Diez M, Katragkou E, Krüzselyi I, Mayer S, Soares P, Sobolowski S, van Meijgaard E, Vautard R, Warrach-Sagi K, Wulfmeyer V (2017) Land-atmosphere coupling in EURO-CORDEX evaluation experiments. Journal Geophys Res Atmos 122:79-103. https://doi.org/10.1002/2016JD025476

Koskou T, Allouhi A, Belattar M, Jamil A, El Rhafiki T, Zeraouli Y (2015) Morocco's strategy for energy security and low-carbon growth. Energy 84(2015):98-105 https://doi.org/10.1016/j.energy.2015.02.048

Kühne, R. (2019). Climate change: the science behind Greta Thunberg and Fridays for future. https://oi. org/10.31219/osf.io/2n6kj

Lejeusne C, Chevaldonné P, Pergent-Martini C, Boudouresque C, Pérez T (2010) Climate change effects on a miniature ocean: the highly diverse, highly impacted Mediterranean Sea. Trends in Evolution and Ecology 25(4):250-260. https://doi.org/10.1016/j.tree.2009.10.009

Maor M, Tosun J, Jordan A (2017) Proportionate and disproportionate policy responses to climate change: core concepts and empirical applications. Journal of Environmental Policy \& Planning 19(6):599-611. https://doi. org/10.1080/1523908X.2017.1281730 
MAPAMA (2017) Séptima comunicación nacional de España: Convención Marco de las Naciones Unidas sobre el Cambio Climático [Seventh national communication of Spain: UNFCCC]. Ministerio de Agricultura y Pesca, Alimentación y Medio Ambiente NIPO 013180194 https://www.miteco.gob.es/es/red-parquesnacionales/boletin/7cn_web_tcm30-438294.pdf

Meinhausen M, Alexander R (2017) Morocco factsheet, "Fiji COP23" edition. In: Based on PRIMAP. AMPERE Team. University of Melbourne, CAIT, CDIAC, EDGAR, IPCC, IEA, UNEP GAP Team Available at www. climatecollege.unimelb.edu.au/indc-factsheets

MEMEE (2016) Premier Rapport Biennal Actualisé du Royaume du Maroc. [First Updated Biannual Report of Moroccan Kingdom]. Ministère Délégué auprès du Ministre de l'Energie, des Mines, de l'Eau et de l'Environnement Chargé de l'Environnement (Avril 2016)

Moustakbal J (2017) Despotism neoliberalism and climate change: Morocco's catastrophic convergence. Middle East Eye (21 July 2017) http://www.middleeasteye.net/essays/catastrophic-convergence-1321268571

MTE (2019) Inventario Nacional de emisiones a la atmósfera - Emisiones de Gases de Efecto Invernadero, Edición Enero 2019. [National Inventory of atmospheric emissions - Greenhouse Gas Emissions, January 2019 Edition] Ministerio para la Transición Ecológica

Muñoz-Díaz D, Rodrigo F (2004) Spatio-temporal patterns of seasonal rainfall in Spain (1912-2000) using cluster and principal component analysis: comparison. Ann Geophys 22:1435-1448

OECDStat (2019) OECD Environment Database, based on National Inventory Submissions 2018 to the UNFCCC. Consulted on February 2019

OS (2017) Empresas más contaminantes 2017.[Most contaminant companies 2017]. Observatorio de la Sostenibilidad. Available at: https://www.observatoriosostenibilidad.com/2018/05/31/empresas-mascontaminantes-2017-2/

Paris Equity Check (2019) A multidimensional equity and warming assessments of national climate pledges, Robiou du Pont, Y.. Available at: http://paris-equity-check.org/warming-check.html\#open-graph

Peters B, Jordan A, Tosun J (2017) Over-reaction and under-reaction in climate policy: an institutional analysis. Journal of Environmental Policy \& Planning 19(6):612-624. https://doi.org/10.1080/1523908 X.2017.1348225

Rios-Entenza A, Soares P, Trigo R, Cardoso R, Miguez-Macho G (2014) Moisture recycling in the Iberian Peninsula from a regional climate simulation: spatiotemporal analysis and impact on the precipitation regime. J Geophys Res Atmos 119:5895-5912. https://doi.org/10.1002/2013JD021274

Robiou du Pont, Y, Meinshausen M (2018) Warming assessment of the bottom-up Paris Agreement emissions pledges. Nature Communications 7, (2018), available at: https://doi.org/10.1038/s41467-018-07223-9

Saidi A, Diouri M (2017) Food self-sufficiency under the Green-Morocco Plan. Journal of Experimental Biology and Agricultural Sciences, Horizon Publisher India 2017, 5 (Spl-1- SAFSAW), pp.33-40. <https://doi. org/10.18006/2017.5(Spl-1-SAFSAW).S33.S40>. <halshs-01613992>

Serrano A, Garcia J, Mateos V, Cancillo M, Garrido J (1999) Monthly modes of variation 625 of precipitation over the Iberian Peninsula. J Clim 12:2894-2919

Soares P, Cardoso R, Miranda P, Viterbo P, Belo-Pereira M (2012a) Assessment of the ENSEMBLES regional climate models in the representation of precipitation variability and extremes over Portugal. J Geophys Res 117:D07114. https://doi.org/10.1029/2011JD016768

Soares P, Cardoso R, Miranda P, de Medeiros J, Belo-Pereira M, Espírito-Santo F (2012b) WRF high resolution dynamical downscaling of ERA-Interim for Portugal. Clim Dyn 39:2497-2522. https://doi.org/10.1007 /s00382-012-1315-2

Soares P, Cardoso R, Lima D, Miranda P (2017) Future precipitation in Portugal: high-resolution projections using WRF model and EURO-CORDEX multi-model ensembles. Clim Dyn 49:2503-2530. https://oi. org/10.1007/s00382-016-3455-2

Spash C (2016) This changes nothing: the Paris agreement to ignore reality. Globalizations, 2016 13(6):928-933. https://doi.org/10.1080/14747731.2016.1161119

Turco M, Palazzi E, Von Hardenberg J, Provenzale A (2015) Observed climate change hotspots. Geophys Res Lett 42(9):3521-3528

UNFCCC (2017). The Paris Agreement - main page. [online] Available at: http://unfecc.int/paris agreement/items/9485.php. Accessed 9 Mar 2019

Publisher's note Springer Nature remains neutral with regard to jurisdictional claims in published maps and institutional affiliations. 


\section{Affiliations}

João Camargo ${ }^{1}$ • Iñaki Barcena ${ }^{2} \cdot$ Pedro M. Soares $^{3} \cdot$ Luísa Schmidt $^{1} \cdot$ Javier Andaluz $^{4}$

Iñaki Barcena

inaki.barcena@ehu.es

Pedro M. Soares

pmsoares@fc.ul.pt

Luísa Schmidt

mlschmidt@ics.ulisboa.pt

Javier Andaluz

clima@ecologistasenaccion.org

1 Instituto de Ciências Sociais, Universidade de Lisboa, Av. Prof. Aníbal de Bettencourt, 9, 1600-189 Lisbon, Portugal

2 Facultad de Ciencias Sociales y de la Comunicación, Universidad del Pais Vasco, Bilbao, Spain

3 Instituto D. Luiz, Faculdade de Ciências, Universidade de Lisboa, Lisbon, Portugal

4 Departmento de Cambio Climatico de Ecologistas en Acción, Madrid, Spain 